Rapp. Grønlands geol. Unders. 48, 93-98 (1972)

\title{
REMARKS ON THE QUATERNARY GEOLOGY OF JAMESON LAND AND ADJACENT AREAS, SCORESBY SUND, EAST GREENLAND
}

\author{
Svend Funder
}

\section{Introduction}

During the summer of 1971 mapping of Quaternary geology was carried out in the eastern part of the Scoresby Sund region: along the coasts of Jameson Land, at the head of Carlsberg Fjord, around Scoresbysund settlement and at the mouth of Schuchert Dal to the north of Hall Bredning.

Observations made by K. Birkenmajer and M. Aellen on the distribution of erratic boulders and extent of glaciation in areas to the south and south-west of Carlsberg Fjord and along the east side of Schuchert Dal were kindly made available to me.

The work this summer marked the completion of a 'three summer project' of Quaternary mapping in the region. Some results from the first two summers have been published previously (Funder, 1970, 1971).

In the map (map 4) some significant field observations have been presented. The distribution of 'Jameson Land plateau drift deposits' on the map is mainly based on observations by F. Surlyk and T. Birkelund which kindly have been put at my disposal. Sample localities of $\mathrm{C}^{14}$ dates are plotted on the map; a list of these dates with short abstracts is found at the end of this report.

\section{Jameson Land plateau drift deposits}

Jameson Land is composed of Mesozoic sedimentary rocks with an almost horizontal bedding. In the interior the sandstone beds form extensive plateaux at altitudes up to $1100 \mathrm{~m}$; many of the high plateaux are covered with drift deposits up to $30 \mathrm{~m}$ thick. These peculiar deposits have attracted the attention of most geologists working in the area, and according to their descriptions the dominant type of sediment is a coarse till (Rosenkrantz, 1929; Aldinger, 1935; Birkelund \& Perch-Nielsen, 1969), but deposits of rounded and well sorted gravel have also been observed (Nordenskjöld, 1907; Callomon, 1970). 
Stone counts made by the author on a till covered plateau $800 \mathrm{~m}$ above sea level near J.P. Koch Fjeld, show that more than $60 \%$ of the stone content in the till has been transported from areas outside Jameson Land; one type, a gneiss rich in garnet, which makes up more than $25 \%$ in the counts, probably originates in the area of metamorphic rocks to the west of Hall Bredning more than $150 \mathrm{~km}$ away where gneiss of this type occurs abundantly.

A further distinctive rock type found in the till is Scolithus quartzite that occurs with low but constant values in the counts. Erratics of Scolithus quartzite have frequently been observed in East Greenland, and their distribution has recently been discussed by Haller (1971, fig. 48). During the GGU expeditions erratics of Scolithus quartzite have been observed in all parts of the Scoresby Sund region, the southernmost occurrence being at Kap Brewster at $70^{\circ} \mathrm{N}$ (Birkenmajer, personal communication). In spite of its widespread occurrence as an erratic boulder Scolithus quartzite has never been found in situ in central East Greenland, and it was suggested by Cowie \& Adams (1957) and Haller (1971) that its occurrences are hidden beneath the Inland Ice to the west and north-west of the Scoresby Sund region.

A third type of indicator boulder in the region is a characteristic augen granite rich in garnet observed as an erratic boulder in Liverpool Land by N. Henriksen (personal communication) and known in situ only from areas to the west of Hall Bredning.

The evidence of the indicator boulders shows that the region was once totally covered with ice, the general direction of ice movement being from the west or north-west. The high-lying drift deposits in Jameson Land indicate that the ice had a considerable thickness, and it probably extended beyond the outer coast and into the sea.

There is no evidence for a direct dating of this ice cover; the topographical setting of the deposits and their boulder content indicate conditions of glaciation very different from those known from younger deposits; therefore a preWeichselian, possibly a Saalian age is suggested.

\section{The Flakkerhuk moraine}

For a distance of $40 \mathrm{~km}$ along South Jameson Land the coast is made up of a ridge behind which all major streams have been deflected and run parallel to the coast (fig. 14). The ridge is up to $80 \mathrm{~m}$ high and $500 \mathrm{~m}$ wide and in stream sections it is seen to rest on Mesozoic sedimentary rocks near sea level. It is composed of sorted silt grading upwards into sand and gravel; over the flat top erratic boulders are scattered and at a few localities the ridge is capped by mounds of unsorted till. 
Where studied, the layering of the sorted sediments appears to be undisturbed and almost horizontal.

The ridge was first observed by Aldinger (1935) who believed it to be a lateral moraine deposited by a large glacier in Scoresby Sund. Abundant erratics of basalt and sandstones from the Kap Stewart Formation (U. Asgaard, personal communication) indicate transport from the south or south-west.

Although the formation of the ridge is probably more complex than held by Aldinger, the assumption of a glacier in adjacent parts of Scoresby Sund seems inevitable for its formation; the name 'The Flakkerhuk moraine' is therefore proposed for the ridge.

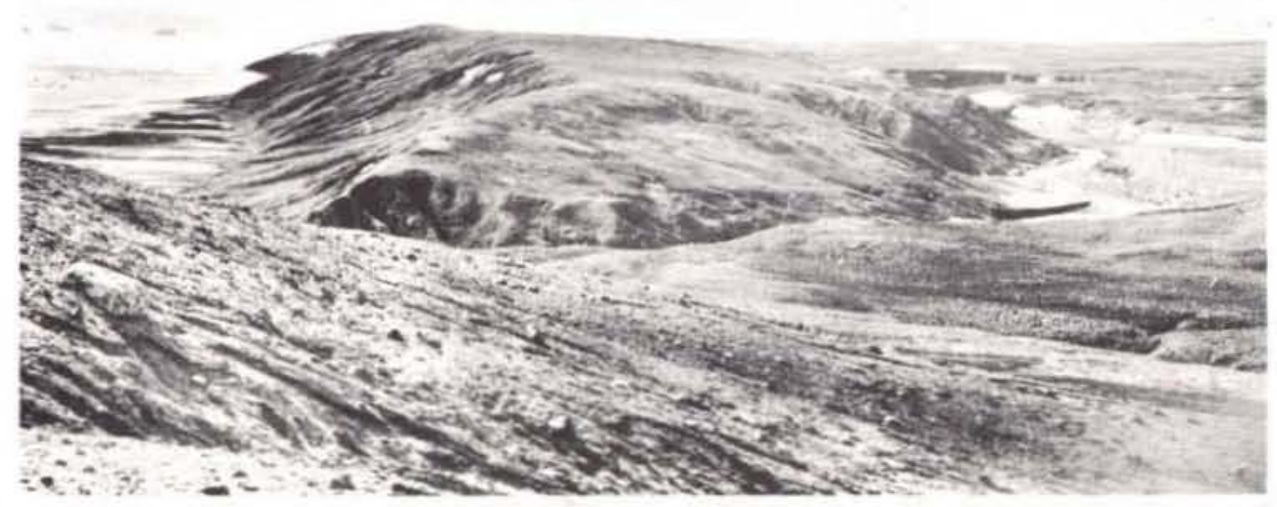

Fig. 14. The Flakkerhuk moraine at Kap Stewart, looking eastwards. The moraine rises $70 \mathrm{~m}$ above the sea level of Scoresby Sund which is seen to the left.

The Flakkerhuk moraine is taken as evidence for a period of extensive glaciation during which the wide Scoresby Sund served as an outlet trough for a large glacier, comparable in size to present large outlet glaciers in North Greenland.

The presence of large driftless areas outside the moraine indicates that it forms a significant glaciation boundary and its topographical setting makes it possible that the moraine represents the maximum of Weichselian glaciation in the region. This assumption agrees with the view held by Washburn (1965), that during the maximum of the Weichselian glaciation the coastal mountains at Kong Oscars Fjord to the north of Scoresby Sund were ice free while the fjord was occupied by a large outlet glacier.

A sample of fragments of bivalve shells collected in the silt in the lower part of the Flakkerhuk moraine has been $\mathrm{C}^{14}$ dated to more than $35000 \mathrm{yr}$ B.P. (sample 146503). Since it cannot be excluded that the shells have been redistributed the date gives little evidence on the age of the moraine. 


\section{The Milne Land Stages}

This name was proposed (Funder, 1970) for some early glacier oscillations during which outlet glaciers from the Inland Ice filled the deep fjords in the interior of the region and had their calving fronts in Hall Bredning. The period was dated relatively by the intersection of moraines by marine shorelines $90-120 \mathrm{~m}$ above present sea level in Milne Land.

During the summer of 1971 moraines representative of the Milne Land Stages were traced in areas near the mouth of the Schuchert Dal to the north of Hall Bredning. The Quarternary geology of parts of this area has been treated previously by Kempter (1961) and Sugden \& John (1965). In this area the moraines of the Milne Land Stages are cut by marine shorelines $105-130 \mathrm{~m}$ above present sea level. Through the kind help of D.E. Sugden and B. S. John it has been possible to obtain material for dating the lower of these shorelines, and the termination of the period of the Milne Land Stages in the area. The date obtained, $9900 \mathrm{yr}$ B.P. (sample 146510), fixes this event in the Pre-Boreal as had been predicted by extrapolation from known younger shoreline-dates (Funder, in press); by further extrapolation a Younger Dryas age (11000-10300 yr B.P.) seems likely for the beginning of the period.

In Hurry Inlet near the outer coast ice marginal features, mainly kame terraces and lateral drainage channels, reflect oscillations during the retreat of a glacier in the fjord. From the direction of glacial striae and from the assemblage of boulders in the till it appears that the glacier was fed by a local ice cap in central Liverpool Land. The rather constant altitudes observed for the marine limit throughout the fjord, $40-50 \mathrm{~m}$ above sea level, seem to indicate a rapid deglaciation of the fjord; a $\mathrm{C}^{14}$ date of $9630 \mathrm{yr}$ B.P. from the area at the head of the fjord indicates the time at which this process was completed (sample 146505). The stages in Hurry Inlet have therefore been correlated with the Milne Land Stages farther to the west in the region. It should be mentioned however, that whereas the moraines at Hall Bredning seem to reflect distinct advances, the character of the deposits in Hurry Inlet seems rather to be indicative of minor halts during recession.

\section{Post-Milne Land Stages}

Ice marginal features relating to the Postglacial recession of fjord glaciers in the innermost fjord branches in the region have earlier been described under the name 'The Rødefjord Stages', (Funder, 1971); they represent halts or minor oscillations during retreat in the period $7500-6700 \mathrm{yr}$ B.P.

It has not been possible to date any corresponding oscillations in the coastal part of the region. However, moraines in front of outlet glaciers from the Liverpool Land ice cap reflecting minor prehistoric oscillations have been observed; they 
could possibly correspond to some of the oscillations known from the interior. It should also be mentioned that judged from the altitudes of marine limits (map 4) Carlsberg Fjord, to the north of Hurry Inlet, seems to have been deglaciated at a much later time than was the case for Hurry Inlet.

\section{Marine limits and post-glacial rebound}

Observations on marine limits in the area have been plotted on the map (map 4). The marine limit marks the highest elevation of sea level at a site after its deglaciation. The limit appears as a boulder shoreline, or a boundary between unsorted till and till from which the fines have been removed by wave action; raised deltas may be associated with the limit. In some areas the marine limit can be very difficult to define; this is the case in western and southern Jameson Land where intense solifluction has tended to obliterate indications of the older shorelines.

In the areas at the mouth of Schuchert Dal, in Hurry Inlet and probably around the Scoresbysund settlement the marine limit was formed immediately after the deglaciation of these areas. The altitudes of the marine limits in these areas decrease towards the east and $\mathrm{C}^{14}$ dates show that the decrease is due to differential uplift resulting in tilting of the synchronous shorelines (samples 146506, 146510). The exact amount of tilt, however, cannot be calculated since the trend of the isobases in the region is not yet known; measured from east to west it amounts to approximately $0.4 \mathrm{~m} / \mathrm{km}$.

According to the deglaciation history outlined above western and southern Jameson Land probably became deglaciated much earlier than the areas at Schuchert Dal and Hurry Inlet, and the marine limit possibly was formed during the period of maximum submergence in the region. The dating of the marine deposits in Jameson Land, however, has met with some problems. Three samples of bivalve shells obtained from deposits of marine silt over a distance of $50 \mathrm{~km}$ along the coast (map 4) have been $\mathrm{C}^{14}$ dated to the period 19500-37000 yr B.P. (samples 106510, 106518, 106524). Since there is no other evidence to support the conclusion that large parts of the Scoresby Sund region were ice free and open to the sea during the very cold upper Weichselian (Dansgaard et al., 1970) these dates probably should be regarded with suspicion.

The bivalve species found in the marine deposits all live in the area to-day, and the faunas contain no indication of the rapid sedimentation that is usual in the proximity of a glacier. The shells were all well preserved and mainly found in situ, so redistribution seems unlikely. As possible sources of error it is suggested that the original shell substance may have been contaminated by either "old" carbon, resulting in too high ages for Late or Postglacial animals, or with "young" carbon causing a "rejuvenation" of animals that may have lived during the warm mid- 
Weichselian interval (Dansgaard et al., 1970). However, it is not easy to imagine the source for a contamination of this size in an area devoid of carbonate sediments, and it is hoped that further $\mathrm{C}^{14}$ datings from the area will help to solve the problem.

If the altitudes of marine limits in map 4 are compared with observations from the previous years in the interior parts of the region (maps in Funder, 1970 and 1971 ) it appears that the highest marine limits observed in the region, 120-130 m a. s. 1., were associated with ice frontal deposits from the Milne Land Stages at the northern and western coasts of Hall Bredning; farther west the marine limits decrease in height due to later deglaciation. This pattern possibly indicates that a great part of the isostatic rebound in the region occurred as a response to the rapid thinning of ice that took place after Younger Dryas time.

\section{References}

Aldinger, H. 1935: Geologische Beobachtungen im Oberen Jura des Scoresbysundes. Meddr Gronland 99, 1, 128 pp.

Birkelund, T. \& Perch-Nielsen, K. 1969: Field observations in upper Palaeozoic and Mesozoic sediments of Scoresby Land and Jameson Land. Rapp. Gronlands geol. Unders. 21, 21-36.

Callomon, J. H. 1970: Geological map of Carlsberg Fjord - Fossilbjerget area. Meddr Gronland $168,4,10 \mathrm{pp}$.

Cowie, J.W. \& Adams, P. J. 1957: The geology of the Cambro-Ordovician rocks of central East Greenland. Meddr Gronland 153, 1, 194 pp.

Dansgaard, W., Johnsen, S. J., Clausen, H. B. \& Langway, C.C. 1970: Ice cores and paleoclimatology. In Olsson, I. U. (editor) Radiocarbon variations and absolute chronology. 337-355. Stockholm: Almqvist \& Wiksell.

Funder, S. 1970: Notes on the glacial geology of eastern Milne Land. Rapp. Grønlands geol. Unders. 30, 37-42.

Funder, S. 1971: Observations on the Quaternary geology of the Rødefjord region, Scoresby Sund, East Greenland. Rapp. Gronlands geol. Unders. 37, 51-55.

Funder, S. in press: Deglaciation history in the fjords of Scoresby Sund, North East Greenland. Spec. Publs Inst. Br. Geogr. 4.

Haller, J. 1971: Geology of the East Greenland Caledonides. Interscience, London, 413 pp.

Kempter, E. 1961: Die jungpaläozoischen Sedimente von Süd Scoresby Land. Meddr Grønland $164,1,123$ pp.

Nordenskjöld, O. 1907: On the geology and physical geography of East Greenland. Meddr Gronland 28, 151-284.

Rosenkrantz, A. 1929: Preliminary account on the geology of the Scoresby Sound district. Meddr Gronland 73, 2, 133-154.

Sugden, D. E. \& John, B.S. 1965: The raised marine features of Kjove Land, East Greenland, Geogrl J. 131, 235-247.

Washburn, A. L. 1965: Geomorphic and vegetational studies in the Mesters Vig district. Meddr Gronland 166, 1, $60 \mathrm{pp}$. 